STATE OF ALASKA

DEPARTMENT OF NATURAL RESOURCES

\title{
GEOLOGICAL LITERATURE ON THE COPPER RIVER AND MIDDLE TANANA RIVER BASINS, ALASKA
}

Compiled by K.S. Emmel and P.L. Coonrod

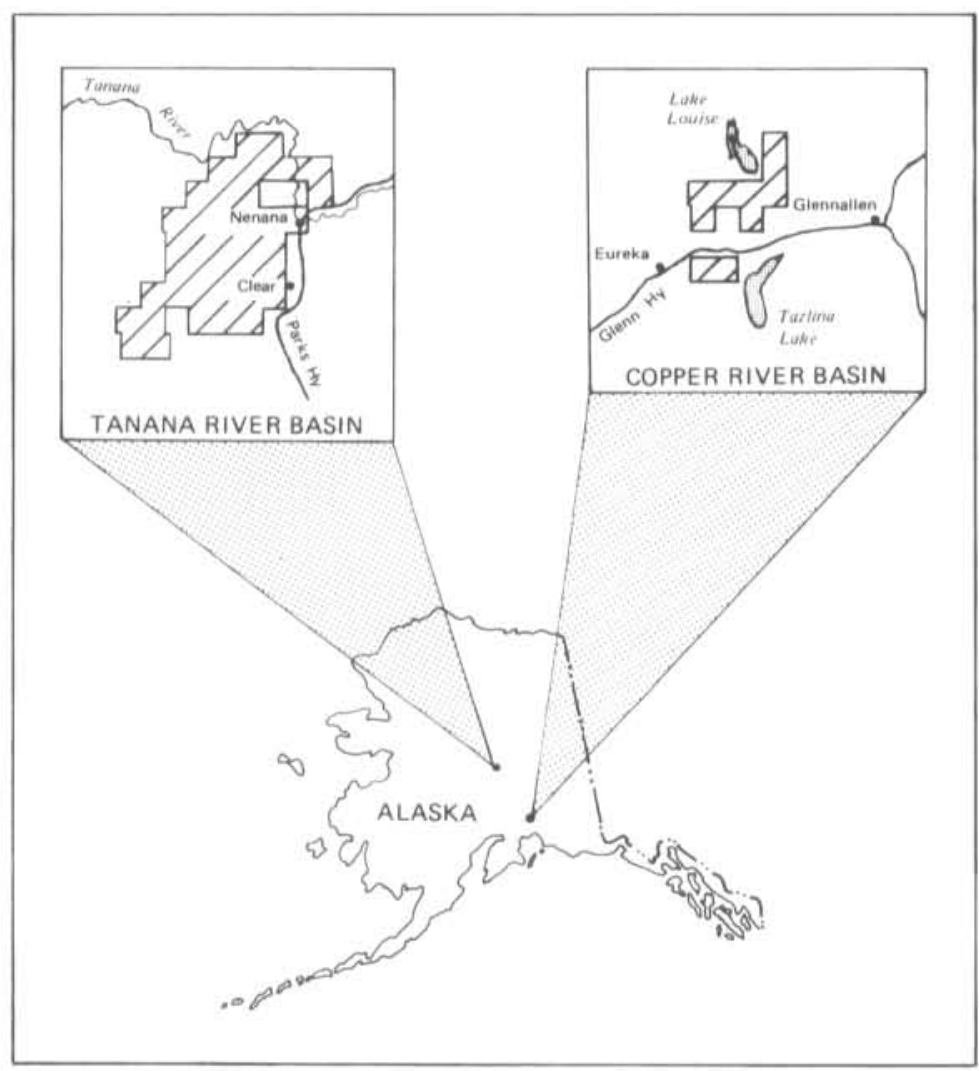

SPECIAL REPORT 30

Published by

DIVISION OF GEOLOGICAL \& GEOPHYSICAL SURVEYS

ANCHORAGE, ALASKA

1982

ROSS G, SCH AFF

STATE GEOLOGIST 
SPECIAL REPORT 30

\section{GEOLOGICAL LITERATURE ON THE COPPER RIVER AND MIDDLE TANANA RIVER BASINS,} ALASKA

Compiled by K.S. Emmel and P.L. Coonrod

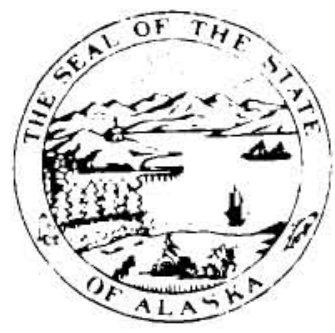

ANCHORAGE, ALASKA 


\section{STATE OF ALASKA}

Jay S. Hammond, Governor

John W. Katz, ('ommissioner, Depl. of Natural Resources

Geoffrey Haynes, Deputy' ('ommissioner

Ross G. Schaff, Stale (icologist

Cover: Map showing locations of Copper River and middle Tanana Riter hasins, Alaska.

A vailable from Alaska Division of Geological and Geophysical Surveys, P.O. Box 80007, College, 99708: 323 F. 4th, Anchorage, 99501 : P.O. Box 2438, Ketchikan, 99901 ; and 230 So. Franklin, Juneau, 99811 , Cost: $\$ 1$. 


\section{CONTENTS}

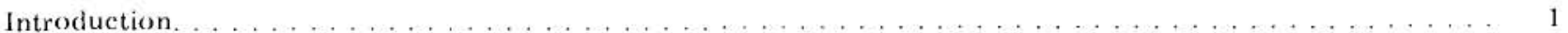

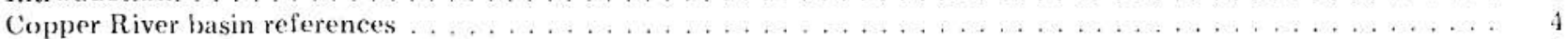

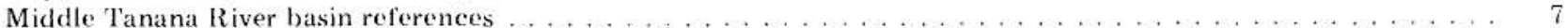

\section{FIGURES}

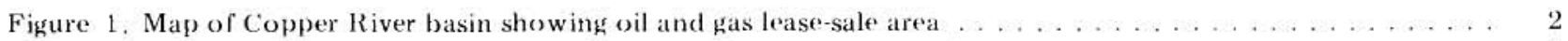

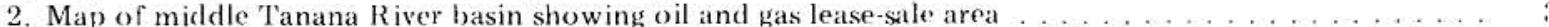




\section{INTRODUCTION}

T'hese bibliographies cite most geological literature published on the Copper River and middle Tanana River basins. The area was the subject of an oil and gas lease sale in August 1982 (figs. 1 and 2). Because of this, petroleum-related entries were emphasized.

The annual bibliographies of li.ll. Cobb (lis. (ieological Survey) and the Bibliography and Index of (ieology (American (ieological Institute) were the primary sourees for this compilation. No attempt was made to verify information from the original documents.

Corrections and additions are welcomed by the authors. 


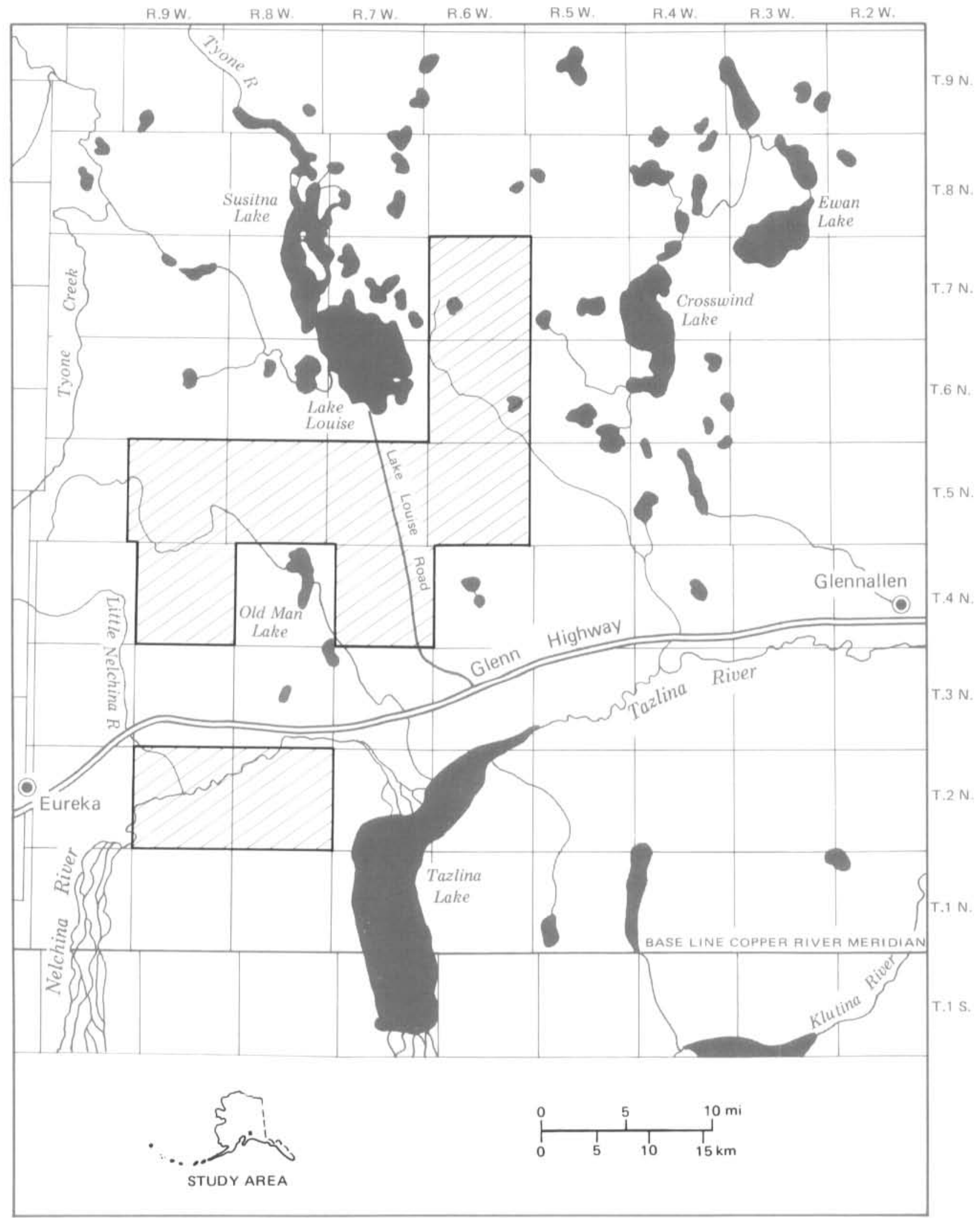

Figure 1. Map of Copper River basin showing oil and gas lease-sale area. 


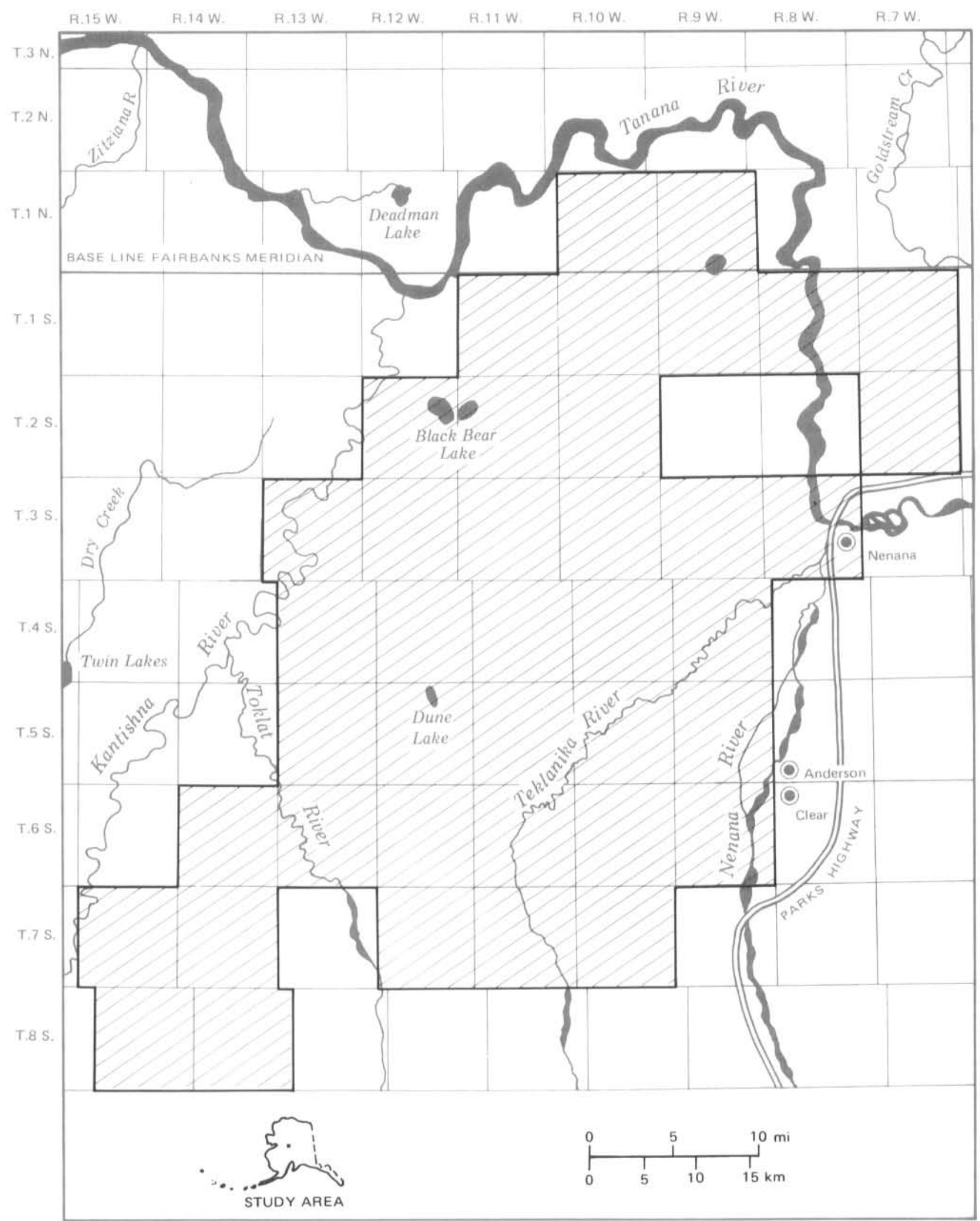

Figure 2. Map of middle Tanana River basin showing oil and gas lease-sale area. 


\section{COPPER RIVER BASIN REFERENCES}

Alaska Division of (ieological and (ieophysical Surveys, 1973, Aeromagnetic map, northeast corner of (iulkana Quadrangle, Alaska: Division of (ieological and (ieophysical Surveys ()pen-file Report 12, scale 1:250,000.

Andreasen, (i.E., Dempsey, W.J., Henderson, J.R., Jr., and (iilbert, F.P., 1958, Aeromagnetic map of the ('opper River basin, Alaska: U.S. (ieological Survey Geophysical lnvest igations Map) (iP-156, scale 1:125,000.

Andreasen, (i.E., (irant\%, Arthur, Ziet\%, Isidore, and Barnes, D.F., 196.4, Geologic interpretation of magnetic and gravity data in the copper River basin, Alaska: U.S. Cieological Survey Professional Paper 316-H, p. $135-153$.

Barnes, D.F., 1967, Four preliminary gravity maps of parts of Alaskat: L's. Cieological Survey Open-file Report $67-10$, sp.

, 1977a, Preliminary Bouguer gravity map of central Alaska: U.S. Geological Survey Open-file Report $77 \cdot 168 \cdot(;$, scale $1: 1,000,000$.

, $1977 \mathrm{~b}$, Gravity map of the eastern part of southern Alaska: L.S. (ieological Survey Open-file Report $77 \cdot 169 \cdot(\mathrm{C}$, scale $1: 1,000,000$.

Beikman, II.M., 1974, Preliminary geologic map of the southeast quadrant of Alaska: U.S. (ieological Survey Miscellaneous Field Studies Map MF-612, scale $1: 1,000,000,2$ sheets.

Beikman, H,M., Holloway, (.D., and MacKevett, F.M., Jr., 1977, (ieneralized geologic map of the eastern part of southern Alaska: U.S. (ieological Survey Open-file Report 77-169-B, scale 1:1,000,000,

Berk, H.C., Jones, D.L., and Richter. D.H., 1972, (iravina-Nutzotin belt - Tectonic significance of an upper Me'sozoic sedimentary and volcanic sequence in southern and southeastern Nlaska, in (ieological Survey research 1972: U.S. Cieological Survey Professional Paper 800-D, p. D1-D24.

Bottge, R.G., 1975, Impact of a natural gas pipeline on mineral and energy development in Alaska: U.S. Bureau of Mines Open-file Report 20-75, also available as National 'T'echnical Information Service PF $240638 / \mathrm{AS}, 101$ maps, $177 \mathrm{p}$.

Carlson, P.R., and Molnia, B.F., 1978, Minisparker profiles and sedimentologic data from R/V ACONA cruise (April 1976) in the Gulf of Alaska and Prince William Sound: U.S. (ieological Survey Open-file Report $78-381,2$ pl., $33 \mathrm{p}$.

Case, J.E., Barnes, D.F., Plafker, (ieorge, and Robbins, S.L., 1966, (iravity survey and regional geology of the Prince William Sound epicentral area, Alaska: U.S. Geological Survey Professional Paper 543-C, p. C1-C12.

Churkin, Michael, Jr., 1973, Paleozoic and Precambrian rocks of Alaska and their role in its structural evolution: U.S. (ieological Survey Professional Paper 740,64p.

Coulter, H.W., and Coulter, E.B., 1961, (irology of the Valde\% (A.5) (Quadrangle, Alaska: U.S. (ieological Survey Quadrangle Map (iQ.142, scale 1:63,360.

1962, Preliminary geologic map of the Valdez Tiekel belt, Alaska: U.S. (ieological Survey Miscellaneous Geologrical Investigations Map 1-356, scale 1:96,000.

Coulter, H.W., and Migliaccio, R.R., 1966, Effects of the earthquake of March 27, 196.1, at Valdez, Alaska: U.S. (ieological Survey Professional Pajer 5.42-C, p. C'1.C36.

Dadisman, S.V., 1980, Radiometric ages of rocks in south-central Alaska and western Yukon Territory: U.S. Geological Survey Open-file Report $80-183,80 \mathrm{p}$.

Decker, J.E., and Karl, Susan, 1977 a, Preliminary aeromagnetic map of central Alaska: U.S. (ieological Survey Open. file Report 77-168E, scale 1:1,000,000.

, $1977 \mathrm{~b}$, Preliminary aeromagnetic map of the eastern part of southern Alaska: U.S. (ieological Survey Open-file Report 77-169E, scale 1:1,000,000.

Eberlein, G.D., Gassaway, J.S., and Beikman, H.M., 1977, Preliminary geologic map of central Alaska: U.S. (ieological Survey Open-file Map 77-168A, scale 1:1,000,000.

Ferrians, O.J., Jr., 1966, Effects of the earthquake of March 27, 1964, in the Copper River hasin area, Alaska: U.S. (ieological Survey Professional Paper 5-43-E, p. F1-E2X.

1971, Preliminary engineering geologic maps of the proposed trans-Alaska pipeline route, Gulkana Quadrangle: U.S. Geological Survey Open-file Report 71-102, scale 1:125,000, 2 sheets.

Fogleman, K.A., Stephens, C.D., Lahr, J.C., Helton, S.M., and Allan, M.A., 1978, Catalog of earthquakes in southern Alaska, October-December 1977: U.S. (ieologicat Survey Open-file Report 78-1097, 28 p.

Forbes, R.B., Carden, J.R., and Zdepski, J.M., 1977, The origin of low-level airborne radiometric anomalies in the Copper River basin region, Alaska: Boulder, U.S. Department of Energy Report (iJBX-62(77), 57 p.

Gerin, Marybeth, and Molnia, B.F., 1978, Gazetteer of coastal and offshore features of the Gulf of Alaska north of $54^{\circ} \mathrm{N}$. latitude: U.S. (ieological Survey Open-file Report $78-208,63 \mathrm{p}$.

Grantz, Arthur, 1964, Stratigraphic reconnaissance of the Matanuska Formation in the Matanuska Valley, Alaska: U.S. Geological Survey Bulletin 1181-I, P. I1-I33.

Grantz, Arthur, Jones, D.L., and Lanphere, M.A., 1966, Stratigraphy, paleontology, and isotopic ages of upper Mesozoic rocks in the southwestern Wrangell Mountains, Alaska, in Cieological Survey research 1966: U.S. Geological Survey Professional Paper 550-C, p. C39-C47.

Grantz, Arthur, Plafker, George, and Kachadoorian, Reuben, 1964, Alaska's Good Friday earthquake, March 27, 1964, a preliminary evaluation: U.S. Ceological Survey Circular 491, 35 p. 
Ilansen, W.R., Eckel, E.B, Schaem, W.E., Lyle, R.F., (ieorge, Warren, and Chance, (ienie, 1966, The Nlaska earthquake, March 27, 1964: Field investigations and reconstruction effort: U.S. Cieological Survey Protessional Paper $511,111 \mathrm{p}$.

Henning, M.W, 1973, (ieology and mineral review of the Bremner River drainage: Alaska Division of Geological and (ieophysical Surveys Open-file Report $2 \cdot 1,13$ p.

Henning, M.W., and Dobey, P.L., 1973, Geologic and mincral evaluation of the Chitina and Bremner River dratinage basins: Alaska Division of (ieological and (ieophysical Surveys Open-file Report 25, $25 \mathrm{p}$.

Herreid, Ciordon, 1969, Cieology and geochemistry of the Spirit Mountain area, Valdez Quadrangle, Alaska [abs. ], in Alaska Division of Mines and (ieology Annual Report for 1969, p. 11-12.

1970, (reology of the Spirit Mountain nickel-copper prospect and surrounding area: Alaska Division of Mines and Ceology Cieologic Report 40,19 p., scale 1:125,000.

Hoffman, B.L., 1974, (ieology of the Barnard Mountain area, Tonsina, Alaskat Fairbanks, University of Alaska un published M.S. thesis, $68 \mathrm{p}$.

Jasper, M.W., 1967, (ieochemical investigations along the Valdez to (hitina Highway in south-central Alaska, 1966 Alaska Division of Mines and Minerals (ieochemical Report 1.i, 19 p.

dones, D.L., 1963, Upper (Cretaceous (Campanian and Maestrichtian) ammonites from southern Alaska: U.S. (ieological Survey Professional Paper 432,53 p.

Jones, D.L., 1967, Cretaceous ammonites from the lower part of the Matanuska Formation, southern Alaska: U.S. (ieological Survey Prolessional Paper is $17,49 \mathrm{p}$.

Kachadoorian, Reuben, 1968 , Effects of the earthquake of March 27, 1964 on the Alaska highway system: U.S. (ieological Survey Professional Paper 5.t5-e, P. (:1-C66.

Lahr, J.C., Page, R.A., and Thomas, J.A., 197.1, Catalog of earthquakes in south-central Alaska, April-June 1972: U.S. (ieological Survey Open-file Report $74-1060,35 \mathrm{p}$.

Lahr, J.C., and Stephens, C.D., 1980 , Fastern (iulf of Alaska seismicity: Quarterly report to the National Oceanic and Atmospheric Administration for April 1, 1980 through June 30, 1980: U.S. Cieological Survey Open-file Report $80-943,8 \mathrm{p}$.

Mackevett, K.M., dr, and Plafker, (irorge, 1974, The Border Ranges fault in south-eentral Alaska: U.S. (ieological Survey dournal of Research, v. 2, no. 3, p. 32:3-329.

Marvin, R.F., 1974, A tabulation of K-Ar, Rl)-Sr, and Pl- $\alpha$ ages obtained from materials within the United States (including Alaska and Hawaii) during the years 1965 through 1968 : U.S. Geological Survey Open-file Report $74-1069,245 p$.

Mendenhall, W.C., 1905, (ieology of the central Copper River region, Alaska: U.S. Geological Survey Professional Paper $41,133 \mathrm{p}$.

Mertie, J.B., Jr., 1937, The Yukon-Tanana region, Alaska: U.S. Geological Survey Bulletin 872,276 p.

Metz, P.A., 1975, (ieology of the central portion of the Valdez (-2 Quadrangle, Alaska: Fairbanks, University of $A$ laska unpublished M.S. thesis, $65 \mathrm{p}$.

1976, Occurrences of sodic amphibole-bearing rocks in the Valdez (C-2) Quadrangle: Alaska Division of (ieological and (ieophysical Surveys (ieologic Report 51, p. $27 \cdot 29$.

Nichols, D.R., and Yehle, L.A., 1961, Analyses of gas and water from two mineral springs in the (opper River basin, Alaska, in (ieological Survey research 1961: (T.S. (ieological Survey Professional Paper 124-1), p. D191-D)194.

. 1969, Fingineering geologic map of the southeastern Copper River basin, Alaska: U.s. Geological Survey Miscellaneous (ieological Inventory Map $1-\overline{5} 21$, scale 1:125,000.

Péwé, T.L., 1975, Quaternary geology of Alaska: U.S. (ieological Survey Professional Paper 835, 1.45 p.

Plafker, (ieorge, 1969, Tectonics of the March 27, 196.t Alaska earthquake: U.S. (ieological Survey Professional Paper $543-1$, P. $11-174$.

Plafker, (ieorge, Kachadoorian, Reuben, Fekel, F.B., and Mayo, L.R., 1969, Effects of the earthquake of March 27, 1964 on various communities: U.S. (ieological survey Professional Paper 542-(i, p. (i1-G50).

Plafker, George, and MacNeil, F.S., 1966, Stratigraphic significance of Tertiary fossils from the Orcat (iroup in the Prince William Sound region Alaska, in Geological Survey research 1966: U.S. Cieological Survey Professional Paper $550-\mathrm{B}, \mathrm{p}, \mathrm{B} 62 \cdot \mathrm{B} 68$.

Richter, D.II., 1964, Cieology and mineral deposits of the Ahtell Creek area, Slana district, south-central Alaska: Alaska Division ol Mines and Minerals (ieologic Report 6, $17 \mathrm{p}$.

, 1965, (ieochemical investigation of the Slana district, south-central Alaska, 1963 and 1964: Alaska Division of Mines and Minerals (ieochemical Report 2, $1.1 \mathrm{p}$.

- 1966, Geology of the Slana district, south-central Alaska: Alaska Division of Mines and Minerals (ieologic Report 21 , is $1 \mathrm{p}$.

Richter, D.H., Smith, R.L., Yehle, L.A., and Miller, T.P., 1979, (ieologic map of the (iulkana (A-2) Quadrangle, Alaska: U.S. (ieological Survey (ieological Quadrangle Map (iQ-1520, scale 1:63,360.

Rose, A.W., 1965, (ieology and mineralization of the Midas mine and Sulphide (iulch areas near Valdez, Alaska: Alaska Division of Mines and Minerals (ieologic Report 15, $21 \mathrm{p}$. 
Rose, A.W., and Saunders, R.H., 1965, (ieology and geochemical investigations near Paxson, northern Copper River basin, Alaska: Alaska Division of Mines and Minerals (ieologic Report 13, $35 \mathrm{p}$.

Smith, R.L., and Shaw, H.R., 1979, Igneous-related geothermal systems, in Muffler, L.J.P., red, Assessment of geothermal resources of the United States, 1978: U.S. (ieological Survey (ireular 790, p. 12.17

Smith, R.L., Shaw, H.R., leudke, R. $i$, and Russell, S.L., 1978, (omprehensive tables giving physical datat and thermal energy estimates for young igneous systems of the United States: U.S. Cieological Survey Open-lile Report $78-925$, $28 \mathrm{p}$.

Steele, W.C.., LeCompte, J.R., and Albert, N.R.D., 1979, Landsat data interpretation for various AMRAP quadrangles, Alaska, in Johnson, K.M., and Williams, J.R., eds, The U.S. Geological Survey in Alaska: Accomplishments during 1978: U.S. Geological Survey (ircular 804-B, p. B3-B4.

Stephens, Christopher, and Lahr, J.C., 1979, Seismicity in southern and southeastern Alaskat, in Johnson, K.M., and Williams, J,R., eds., The U.S. Geological survey in Alaska: Accomplishments during 1978: U.S. (ieological Survey Circular $804-\mathrm{B}, \mathrm{p}$. B3-B4.

Stephens, C.I., Lahr, J.C., Fogleman, K.A., Allan, M.A., and Ilelton, S.M., 1979, Catalog of earthquakes in southern Alaska, January-March 1978 : L.S. (ieological Survey (Open-file Report 79-718, $31 \mathrm{p}$.

Stephens, Lahr, J.C., Fogelman, K.A., Helton, S.M., Cancilla, R.S., T'am, Roy, and Baldonado, K.A., 1980, Catalog ol earthquakes in southern Alaska, October-December 1979: U.S. (ieological Survey Open-lile Report $80-2002,53$ p.

Trabant, D.C., 1976, Naska glaciology studies, in ('obb, F.H., ed., The U.S. Cieological Survey in Alaska: Aceomplishments during 1975: U.S. (ieological Survey Circular 733, p. 45-47.

Turner, I.L., (irybeck, Donald, and Wilson, F.H., 1975, Radiometric dates from Alaska*1975 compilation: Naska Division of Geological and (ieophysical Surveys Special Report $10,57 \mathrm{p}$.

Turner, D.L., and Smith, T.E., 197.1, (Feochronology and generalized geology of the central Alaska Range, Clearwater Mountains and northern Talkeetna Mountains: Alaska Division of (ieological and (ieophysical surveys Open-file Report 72, 10 P., plate, scale 1:250,000

Tysdal, R.G., and Plafker, (ieorge, 1978, Age and continuity of the Valdez (iroup), southern Nlaska, in Sohl, N.F., and Wright, W.B., eds., Changes in stratigraphic nomenclature by the LIS. (ieological Survey, 1977: U.S. Geological Survey Bulletin 1457-A, p, A120-A124.

U.S. Cieological Survey, 1960, (ieological Survey research 1960; synopsis of geologic results: U.S. (ieological Survey Professional Paper 400-A, p. A1-A136. , 1961, Geological Survey research 1961 ; synopsis of heologic and hydrologic results: U.S. Geological Survey Professional Paper 424-A, p. A1-A194.

- 1963, Geological Survey research 1963; summary of investifations, prepared by members of the Conservation, (ieologic, and Water Resources Divisions: U.S. (ieological Survey Professional Paper $475-\Lambda, p . A 1$ A300.

- $\overline{\Delta 367}$. - 1964, (ieological Survey research 1964: U.S. (ieological Survey Professional Paper 501-A, P. A1-

, 1965, (ieological Survey research 1965: U.S. (ieological Survey Professional Paper 525. $A, p, A 1$. A376. , 1966, (ieological Survey research 1966: U.S. (ieological Survey Professional Paper 550- A, P. A1 $\mathrm{A} \overline{38} \overline{5}$.

A 425 . , 1967, (ieological Survey research 1967: U.S. Geological Survey Professional Paper 575-A, p. A11972, Geological Survey research 1972: U.S. (ieological Survey Professional Paper 800.A, p. A1 A320. 1973a, (ieological Survey research 1973: U.S. (ieological Survey Professional Paper 850, 366 p. 19731), U.S. Geological Survey Alaska program, 1973: U.S. Geological Survey Circular 683, 56 p. 1974, U.S. (ieological Survey Alaska program, 1974: U.S. Geological Survey Circular 700,63 p. 1976, Geological Survey research 1976: Us. (ieological Survey Professional Paper 1000, 414 p. 1977, (ieological Survey research 1977: U.S. (ieological Survey Professional Paper 1050, 111 p. 1979a, Aeromagnetic map of part of the Valde\% $1^{\circ}$ by $3^{\circ}$ Quadrangle, Alaska: U.S. Geological Survey Open-file Report $79 \cdot 381$, scale $1: 250,000$

, 1979b, (ieological Survey research 1979: U.S. (ieological Survey Professional Paper 1150, 447 p).

White, D.F., and Williams, D.L., eds., 1975, Assessment of geothermal resources of the United States - 1975: U.S. Geological Survey Circular $726,155 \mathrm{p}$.

Wilson, F.H., and Turner, D.L., 1975, Radiometric age map of Alaska--south-central Alaska: Alaska Division of (ieological and Geophysical Surveys Open-file Report 85, $12 \mathrm{p} ., 1$ plate, scale $1: 1,000,000$.

Yehle, L.A., 1980, Preliminary surficial geologic map of the Valdez (C-1) Quadrangle, Alaska: U.S. Geological Survey Miscellaneous Field Studies Map MF-1132, scale 1:63,360.

Yount, M.E., ed., 1975, U.S. (ieological Survey Alaska program, 1975: U.S. Geological Survey Circular 722,58 p. 


\section{MIDDLE TANANA RIVER BASIN REFERENCES}

Alaska Division of (ieological and (ieophysical Surveys, 1973, Aeromagnetic map, southeastern part of Fairbanks

Quadrangle, Alaska: Alaska Division of (ieological and (ieophysical Surveys Open-file Report 8, seate 1:250,000. 1973, Annual lieport, 1972: $57 \mathrm{p}$.

197. Annual Report, 1973:59 p.

1976, Biennial Report, 1971-1975:53 p.

Alaska Idivision of Mines and (ieology, 1968, Annual Report, 1968:67p.

Alaskat Division of Mines and Minerals, 1962, Annual Report, 1962: 119 p.

, 1963, Annual Report, 1963: 87 p.

, 1966, Annual Report, 1966: $115 \mathrm{p}$

, 1967, Annual Report, 196i7: $98 \mathrm{p}$.

American Association of P'etroleum (ieologists, 1978, Alaskat geologic province boundary map: Tulsa, American As sociation of Petroleum (ieologists, scale $1: 1,000,000$.

Andreasen, (i.F., 1960, T'otal intensity aeromagnetic profiles of the Minchumina area, Alaska U.S. (ieological Survey Open-file Report $60-8,3$ sheets.

Andreasen, (i.F., Wahrhaftig, Clyde, and Ziet\%, Isidore, 1961, Aeromagnetic reconnaissance of the east-cent ral T'anana Lowland, Alaska: U.S. (ieological Survey (ieophysical Investigations Map) (iP-1.17.

Barnes, D.F., 1961, (iravity low at Minto Flats, Alaska, in (ieological Survey research, 1961: U.S. (ieological Survey Professional Paper 124-1), p. D25.4-1)257 $\overline{67-10,5 \bar{p} .}$

1967, Four preliminary gravity maps of parts of Alaska: Uf.S. (ieological survey (Open-file Report

, 1971, Preliminary Bouguer anomaly and specitie gravity maps of Seward Peninsulat and Yukon Flats, ATaska: U.S. (ieological Survey Open-file Report 71-1-1, 11 p.

, 1977a, Preliminary Bouguer gravity map of central Alaska: U.S. (ieological Survey Open-lile Report

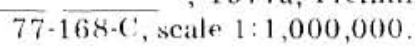

, 1977b, (iravity map of the eastern part of southern Alaska: U.S. (ieological survey Open-file Report $77-169-\mathrm{C}$, seale $1: 1,000,000$

Barnes, F.F., 1967, Coal resources of Alaska: U.S. Cieological Survey Bulletin 1212-B, p. B1-B:36.

Beikman, H.M., 1974a, Preliminary geolugie map of the southwest quadrant of Alaska: L'S. (ieological Survey Miscellaneous Field Studies Map MF-611,2 sheets, scale 1:1,000,000.

, 1974b, Preliminary feologic map of the southeast quadrant of Alaska: U.S. Cicological Survey Miscellaneous Field Studies Map MF'-612, 2 sheets, scale 1:1,000,000.

Beikman, H.M., Ifolloway, C.D., and MacKevett, F.M.. Jr., 1977, (ieneralized geologic map of the eastern part of southern Alaska: U.S. Cieological Survey Open-file Report 77-169-B, scale 1:1,000,000.

Beikman, H.M, and Lathram, E.H., 1976, Preliminary geologic map of northern Naska: U.S. (ieological Survey Miscellaneous Field Studies Map MF-789, 2 sheets, scale 1:1,000,000.

Bottge, R.(i, 1975, Impact of a natural gas pipeline on mineral and energy development in Alaska: U.S. Bureau of Mines Open-file Report 20.75, available as National Technical Information Service PB 2.40 $638 / \mathrm{AS}, 101 \mathrm{maps}$ $177 \mathrm{p}$.

Brosge, W.P., Brabh, E.k., and King, E.K., 1970, (ieologic interpretation of reconnaissance aeromagnetic survey of northeatern Alaska: U.S. Cieological Survey Bulletin 1271-F, p. F1-F1.

Brosge, W.P., Lanphere, M.A., Reiser, H.N., and Chapman, R.M., 1969, Probable Permian age of the Rampart (iroup, central Alaska: U.s. Cieological Survey Bulletin 1294-B, p. B1-B18.

Bundtzen, T.K, and Smith, T.F., 1976, Progress report: Cieology and mineral deposits ol the Kantishna Hills, Alaska: Alaska Division of (ieological and (ieophysical Surveys Open-file Report $98,80 \mathrm{p}$.

Bundtzen, T.K., and Turner, D.L., 1979, (ieochronology of metamorphic and igneous rocks in the Kantishna Hills, Mount McKinley Quadrangle, Alaska: Alaska Division of (ieological and Geophysical Surveys (ieologic Report 61, P. $25-30$.

Burand, W.M., 1966, A geochemical investigation of stream sediments in the Nenana Highway area, Alaska: Alaska Division of Mines and Minerals (ieochemical Report 10, $13 \mathrm{p}$.

Capps, S.R., 1940, Geology of the Alaska Railroad region: U.S. Geological Survey Bulletin 907,201 p.

Carter, L.D., and Galloway, J.P., 1978, Preliminary geologic maps of the proposed natural gas pipeline route in the Tanana River valley, Alaska: U.S. (ieological Survey Open-file Report $78-794$, scale 1:125,000, 3 sheets, 29 p.

Chapman, R.M., Yeend, W.E., and Patton, W.W., Jr., 1975, Preliminary reconnaissance geologic map of the western half of Kantishna River Quadrangle, Alaska: U.S. (ieological Survey Open-file Report 75-351, seale 1:250,000.

Churkin, Michael, Jr, 1973, Paleozoic and Precambrian rocks of Alaska and their role in its structural evolution: U.S. (ieological Survey Professional Paper 7.40, 6.4p.

Dadisman, S.V., 1980, Radiometric ages of rocks in south-central Alaska and western Yukon Territory: U.S. (ieological Survey Open-file Report $80-183,80 \mathrm{p}$.

Decker, J.E., and Karl, Susan, 1977a, Preliminary aeromagnetic map of central Alaska: U.S. (ieological Survey Openfile Report $77-168-6$, scale $1: 1,000,000$. 
Decker, J.E, and Karl, Susan, 1977b, Preliminary aeromagnetic profiles of central Alaska: U.S. (ieological Survey Open-file Report 77-168-F, scale 1:1,000,000.

$1977 \mathrm{c}$, Preliminary aeromagnetic map of the eastern part of southern Alaska: U.S. (ieological Survey Open-file Report 77-169-F, scale 1:1,000,000.

Dutro, J.T., Jr., 1979, The Mississippian and Pennsylvanian (Carboniferous) systems in the U.S. - Maska: U.S. (ieological Survey Professional Paper 1110-DD. P. DD1-DD16.

Eberlein, G.D., Gassaway, J.S., and Beikman, H.M., 1977. Preliminary geologic map of central Alaska: Li.S. (ieological Survey Open-file Report $77-168 \Lambda$, scale 1:1,000,000.

Eberlein, G.D., and Menzie, W.D., 1978 , Maps and tables describing areas of metalliferous mineral resource potential of central Alaska: U.S. Geological Survey Open-file Report 78-7D, scale 1:1,000,000, 2 plates. 43 p.

Forbes, R.B., and Weber, F.R., 1975, Progressive metamorphism of schists recovered from a deep drill hole near Fair banks, Alaska: U.S. Geological Survey Journal of Research, v. 3, no. 6, p. 647-657.

Gates, G.O., 1946, Analyses of Alaska coals: L.S. Bureau of Mines Technical Paper 682, $114 \mathrm{p}$.

Gedney, L.D., Shapiro, L.H., Van Wormer, D., and Weber, F.R., 1972, Correlation of epicenters with mapped faults, east-central Alaska, 1968-1971: U.S. Geological Survey Open-file Report 72-128 p.

Gilbert, W.G., 1975), Outline of tectonic history of west-central Alaska Range labs. |: (ieological society of America Abstracts with Programs, v. 7, no. 3, p. 320.

Hansen, W.R., Eckel, E.B., Schaem, W.E., Lyle, R.E., (ieorge, Warren, and Chance, (ienie, 1966, The Alaska earthquake, March 27, 1964: Field investigations and reconstruction effort: L'S. Geological Survey Professional Paper 541,111 p.

Herrera, R.C., 1976, Developments in Alaska in 1976: American Association of Petroleum (ieologists Bulletin, v. 61, no, 8, p. $1157 \cdot 1165$

1978, Developments in Alaska in 1977: American Association of Petroleum Geologists Bulletin, v. 62 , no. 8, p. $1311-1321$

Hiles, R.M., Giryc, George, Dobey, P.L., and Erwin, M.I., 1975, Developments in Alaska in 1974: American Association of Petroleum Geologists Bulletin, $v, 59, \mathrm{no}, 8, \mathrm{p}, 1311.1321$.

Jones, B.C., 1979, Developments in Alaska in 1978: American Association of Petroleum (ieologists Bulletin, v. 63, no. 8, p. $1211 \cdot 1222$

Kaufman, Alvin, 1964, Geothermal power; an economic evaluation: U.S. Bureau of' Mines Information ('ircular 8230 , $24 \mathrm{p}$.

Marvin, R.F., 1974a, A tabulation of K-Ar, Rb-Sr, and Pb- ages obtained from materials within the United States (including Alaska and Hawaii) during the years 1956-1964: U.S. Geological Survey Open-file Report 74-1068, $174 \mathrm{p}$.

1974b, A tabulation of $\mathrm{K}-\mathrm{Ar}, \mathrm{Kb}-\mathrm{Sr}$, and $\mathrm{Pb}-\alpha$ ages obtained from materials with in the United States (including Alaska and Hawaii) during the years 1969-1971: U.S. Geological Survey Open-file Report 74-1070, $193 \mathrm{p}$.

Miller, D.J., Payne, T.G., and (iryc, (ieorge, 1959, (ieology of possible petroleum provinces in Alaska: U.S. Geological Survey Bulletin $535,3 \times \mathrm{p}$.

Miller, T.P., 1973, Distribution and chemical analyses of thermal springs in Alaska: U.S. (ieological Survey Open-file Report $73-187$, scale $1: 250,000,1$ shect.

Miller, T.P., Barnes, Ivan, and Patton, W.W., Jr., 1973, (ieologic setting and chemical characteristics of hot springs in central and western Alaska: U.S. (ieological Survey Open-file Report $73-18 x, 19 p$.

1975, Geologic setting and chemical characteristics of hot springs in west-central Alaska: U.S. (ieological Survey Journal of Research, v. 3, no. 2, p. 149-162.

Mulligan, J.J., 1974, Mineral resources of the trans-Alaska pipeline corridor: U.S. Bureau of Mines Information Circular $8626,24 \mathrm{p}$.

Oliver, W.A., Jr., Merriam, C.W., and Churkin, Michael, Jr, 1975, Ordovician, Silurian, and Devonian corals of Alaska: U.S. Geological Survey Professional Paper 823-B, p. 13-44.

Patton, W.W., Jr., 1978, Map and table describing areas of interest for oil and has in central Alaska: U.s. Geological Survey Open-file Report $78-1 \mathrm{~F}$, scale $1: 1,000,000,2$ sheets, $2 \mathrm{p}$.

Patton, W.W., Jr., and Miller, T.P., 1970, Preliminary geologic investigations in the Kanuti River region, Alaska: U.S. Geological Survey Bulletin 1312-J, p. J1-J10.

Péwé, T.L., 1954, Evidence for possible marine Tertiary(") sediments in central Alaska: American Association of Petroleum (ieologists Bulletin v. 38 , p. 2222-2225

1975a, Quaternary geology of Alaska: U.S. Geological Survey Professional Paper 835, 145 p.

$1975 \mathrm{~b}$, Quaternary stratigraphic nomenclature in unglaciated central Alaska: U.S. Geological Survey Professional Paper 862, 32 p.

Péwé, T.L., Wahrhaftig, Clyde, and Weber, F.R., 1966, Geologic map of the Fairbanks Quadrangle, Alaska: U.S. Geological Survey Miscellaneous Investigations Map [-155, scale 1:250,000, 5 p.

Plafker, George, Kachadoorian, Reuben, Eckel, E.B., and Mayo, L.R., 1969, Effects of the earthquake of March 27, 1964 on various communities: U.S. Geological Survey Professional Paper 542-G, p. G1-G50 
Steele, W.C., LeCompte, J.R., and Albert, N.R.D., 1979, Landsat data interpretation for various AMRAF ituadrangles, Alaska, in Johnson, K.M., and Williams, J.R., eds., The U.S. Geological Survey in Alaska: Accomplishments during 1978: U.S. Geological Survey Circular 804-B, p. B3-B4.

Stephens, C.D., Lahr, J.C., Fogleman, K.A., Allan, M.A., and Helton, S.M., 1979, Catalog of earthquakes in southern Alaska, January-March 1978: U.S. (ieological Survey ()pen-file Report 79-718, 31 p.

Stephens, C.D., Lahr, J.C., Fogleman, K.A., Helton, S.M., Cancilla, R.S., Tam, Roy, and Baldonado, K.A., 1980, Catalog of earthquakes in southern Alaska, (October-December 1979: U.S. Cieological Survey Open-file Report $80-2002,53 \mathrm{p}$.

Townshend, J.B., Papp, J.F., Moorman, M.J., Deadmon, (E.F., and 'Tilton, S.P., 1976a, Preliminary geomaknetic data, College (Observatory, Fairbanks, Nlaska, January 1976: U.S. (ieological Survey Open-lile Report $76-300 \mathrm{~A}, 22$ p. , 1976h, Preliminary geomagnetic data, C'ollege Observatory, Fairbanks, Alaska, February 1976. U.S. Geological Survey Open-file Report 76-300B, $22 \mathrm{p}$.

, $1976 \mathrm{c}$, Preliminary geomagnetic data, College Observatory, Fairbanks, Alaska, March 1976: U.S. Geological Survey (Open-file Report $76-300 \mathrm{C}, 23 \mathrm{p}$. , 1976d, Preliminary geomagnetic data, College Observatory, Fairbanks, Nlaska, April 1976, U.S. Geological Survey Open-file Report 76-300D, $21 \mathrm{p}$. , 1976 e, Preliminary geomagnetic data, College Observatory, Fairbanks, Alaska, May 1976: U.S. Geological Survey Open-file Report $76-300 \mathrm{E}, 20 \mathrm{p}$. , 1976f, Preliminary geomagnetic data, College Observatory, Fairbanks, Alaska, June 1976: U.S. Cieological Survey Open-file Report $76-300 \mathrm{~F}, 20 \mathrm{p}$. , 1976g, Preliminary geomagnetic data, College Observatory, Fairbanks, Alaska, July 1976: U.S. Geological Survey ()pen-file Report $76 ;-300(i, 20 \mathrm{p}$. , 1976h, Preliminary geomagnetic data, College Observatory, Fairbanks, Alaska, August 1976: U.S. Geological Survey Open-file Report $76-300 \mathrm{H}, 21 \mathrm{p}$. , 1976i, Preliminary feomagnetic data, College ()bservatory, Fairbanks, Alaska, September 1976: U.S. (Geological Survey Open-file Report 76-3001, 21 p. , 1976., Preliminary geomagnetic data, College Observatory, Fairbanks, Alaska, October 1976: U.S. Geological Survey Open-file Report $76-300 J, 21 \mathrm{p}$. , $1976 \mathrm{k}$, Preliminary keomagnetic data, College (Observatory, Fairbanks, Nlaska, November 1976: U.S. Geological Survey Open file Report $76-300 \mathrm{~K} .20 \mathrm{p}$. , 19761, Preliminary geomagnetic data, College Observatory, Fairbanks, Alaska, December 1976: U.S. (ieological Survey Open-file Report $76-300 \mathrm{~L}, 21 \mathrm{p}$. , 1977a, Preliminary geomagnetic data, College Observatory, Fairbanks, Alaska, January 1977: U.S. Geological Survey Open-file Report 77-300 A, $20 \mathrm{p}$. , 1977b, Preliminary geomagnetic data, College Observatory, Fairbanks, Alaska, February 1977: U.S. Geological Survey Open-file Report 77-300B, 19 p. , 1977c, Preliminary geomagnetic data, College Observatory, Fairbanks, Alaska, March 1977: U.S. Geological Survey Open-file Report $77-300 C: 20$ p. 1977d, Preliminary geomagnetic data, College Observatory, Fairbanks, Alaska, April 1977: U.S. Geological Survey Open-file Report 77-300D, $20 \mathrm{p}$.

Townshend, J.B., Papp, J.E., Moorman, M.J., and Tilton, S.P., 1977 a, Preliminary geomagnetic data, College (Observatory, Fairbanks, Alaska, May 1977: U.S. (ieological Survey Open-file Report 77-300E, 20 p. 1977b, Preliminary geomagnetic data, College Observatory, Fairbanks, Alaska, June 1977: U.S. Geological Survey Open-file Report 77-300F, 18 p. , 1977c, Preliminary geomagnetic data, College Observatory, Fairbanks, Alaska, July 1977: U.S. Geological S'urvey Open-file Report 77-300(i, 19 p. , 1977d, Preliminary geomagnetic data, College Observatory, Fairbanks, Alaska, August 1977: U.S. Geological Survey Open-file Report $77-300 \mathrm{H}, 20 \mathrm{p}$. 1977 e, Preliminary geomagnetic data, College Observatory, Fairbanks, Alaska, September 1977: U.S. Geological Survey Open-file Report 77-3001, $20 \mathrm{p}$. $1977 \mathrm{f}$, Preliminary geomagnetic data, College Observatory, Fairbanks, Alaska, October 1977: U.S. Geological Survey Open-file Report $77-300 \mathrm{~J}, 20 \mathrm{p}$. , 1977k, Preliminary geomagnetic data, College Observatory, Fairbanks, Alaska, November 1977: U.S. Geological Survey Open-file Report 77-300K, $19 \mathrm{p}$. , $1977 \mathrm{~h}$, Preliminary geomagnetic data, College Observatory, Fairbanks, Nlaska, December, 1977: U.S. Geological Survey Open-file Report 77-300L, $19 \mathrm{p}$. , 1978a, Preliminary geomagnetic data, College Observatory, Fairbanks, Nlaska, January 1978: U.S. Geological Survey Open-file Report $78.300 \mathrm{~A}, 20 \mathrm{p}$. , 1978b, Preliminary geomagnetic data, College Observatory, Fairbanks, Alaska, February 1978: U.S. Geological Survey Open-file Report $78-300 B, 21$ p. 
Townshend, J.B., Papp, J.F., and Tilton, S.P., 1978c, Preliminary 5eomagnetic data, College Observatory, Fairbanks, Alaska, May 1978: U.S. (ieological Survey Open-file Report 78-300E, 21 p.

1978d, Preliminary keomagnetic data, College Observatory, Fairbanks, Alaska, June 1978: U.S. Geological Survey Open-file Report $78-300 \mathrm{~F}, 21 \mathrm{p}$.

, 1978 e, Preliminary geomagnetic data, College Observatory, Fairbanks, Alaska, July 1978: U.S.

Geological Survey Open-file Report $78-300(\mathrm{i}, 20 \mathrm{p}$

\section{STAFF}

Ross (i. Schaff, State Geologist

W.W. Barnwell and W.C. Cilbert, Deputy State Geologists

D.D. Adams, Geological assistant

M.D. Albanese, Geological assistant

R.D. Allely, Geological assistant

M.A. Armstrong, Publications speecialist

M.R. Ashwell, Minerals laboratory technician

B.G. Baldwin, Clerk typist

E.E. Becia, Planner

T.A. Benjamin, Chemist

D.L. Bertossa, Geological assistant

J.M. Bird, Clerk-typist

M.E. Brown, Land management officer

T.K. Bundtzen, Geologist

C.D. Burgess, Clerk-typist

L.E. Burns, Geological assistant

S.J. Carrick, Hydrologist

S.L. Chambers, Clerk-ty yist

R.A. Clay, Hydrologist

J. (i. Clough, Geological assistant

E.J. Collazzi, Geological assistant

R.A. Combellick, Geologist

P.L. Coonrod, Secretary

C.L. Daniels, Publications specialist

N.L. Dann, Clerk-typist

J.N. Davies, Geologist

L.L. Dearborn, Hydrologist

J.E. Decker, (ieologist

J.'T. Dillon, (reologist

R.G. Dixon, Archaeologist

G.R, Eakins, Geologist.

S.V. Garbowski, Geologic information technician

D.E. Gibson, Archaeologist

J.J. Hansen, Geophysicist

S.B. Hardy, Geological assistant

M.W. Henning, Geologist

B.S. Hurtig, Systems analyst.

C.E. Holmes, Archaeologist

M.G. Inghram, Hydrologist.

R.W. Ireland, Geologist

S.A. Jacques, Cartographer

J.T. Kline, Geologist

S.L. Klingler, Archaeologist

R.W. Kornbrath, (ieologist

K.J. Krause, Geologist

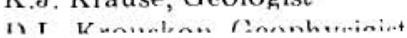

W.M. Lyle, Geologist

C.L. Mahan, Accounting technician

R.A. Mann, Clerk

(i.D. March, Geologist

M.A. Maurer, Hydrologist

(i,A. MeCoy, Hydrologist

D.L. McGee, Geologist

R.D. Merritt, (ieologist

J.F. Meyer, Geophysicist

G.W. Mishler, Archaeologist

W.H. Mitchell, Jr., Geological assistant

M.A. Moorman, Geologist

R.J. Motyka, Geologist

C.G. Mull, Geologist

J.A. Munter, Hydrologist

D.J. Mursch, Clerk-typist

J.N. Newgaard, Accounting technician

C.R. Nichols, Geologist

K.S. Pearson, Cartographer

G.H. Pessel, Geologist

F.H. Pitts, Administrative officer

M.K. Polly, Mineral laboratory technician

M.E. Pritchard, Cartographer

S. E. Rawlinson, Geologist

J.W. Reeder, Geologist

D.R. Reger, Archaeologist

R.D. Reger, Geologist

V.L. Reger, Clerk-ty pist

M.S. Robinson, Geologist

L.C. Schell, Cartographer

R.D. Shaw, Archaeologist

J.A. Sigler, Clerk

T.E. Smith, Geologist

D.J. Solie, Geologist

D.R. Stein, Chemist

R.O. Stern, Archaeologist

C.H. Stevenson, Geologic information technician

M.J. Stroebele, Clerk-typist

R.W. Stuvek, Land management technician

B.A. Syvertson, Clerk-typist

C.A. Ulery, Geological assistant

R.(i. Updike, Geologist

N.C. Veach, Chemist

L) II Wallare Onoratione rocerarsh analuet 